\title{
ZASTRZEŻENIE ZADATKU W UMOWIE DEWELOPERSKIEJ
}

\section{WSTĘP}

Możliwość ustanowienia zadatku w umowie deweloperskiej zasadniczo nie budzi wątpliwości ani w literaturze, ani w praktyce stosowania prawa. Niekiedy jednak jest ona kwestionowana. Skłania to do przeanalizowania tego zagadnienia z uwagi na jego istotne znaczenie praktyczne, ponieważ klauzule zadatku są często zawierane w umowach deweloperskich, a ustawa o ochronie praw nabywcy lokalu mieszkalnego lub domu jednorodzinnego ${ }^{1}$ nie rozstrzyga wprost tego zagadnienia. W razie opowiedzenia się za dopuszczalnościa zastrzeżenia zadatku w umowie deweloperskiej, zasadne jest poczynienie uwag dotyczących sposobu jego ustanowienia.

\section{DOPUSZCZALNOŚĆ USTANOWIENIA ZADATKU W UMOWIE DEWELOPERSKIEJ}

\section{Ważność klauzuli zadatku w kontekście art. 28 ustawy deweloperskiej}

Dominujacy w literaturze pogląd dopuszcza zastrzeżenie zadatku w umowie deweloperskiej ${ }^{2}$ i jest to stanowisko słuszne. Jednakże odosobniona opinia, wyrażana przez Helenę Ciepła, zdaje się taką możliwość wykluczać3 Autorka twierdzi, że elementy umowy deweloperskiej wymienione w art. 22 ustawy deweloperskiej nie stanowią katalogu zamkniętego, więc strony w ramach swobody kontraktowania mogą wzbogacić umowę deweloperską o dodatkowe postanowienia umowne, byle nie były one sprzeczne z przepisami bezwzględnie obowiąujaccymi ani mniej korzystne dla nabywcy - a za takie mniej korzystne postanowienie autorka uznaje zastrzeżenie zadatku ${ }^{4}$. Należy tė̇ uzupełniająco wskazać, że zdaniem Ciepłej art. 29 ustawy dewelo-

\footnotetext{
1 Ustawa z 16 września 2011 r. o ochronie praw nabywcy lokalu mieszkalnego lub domu jednorodzinnego, t.jedn.: Dz. U. 2019, poz. 1805 ze zm. (dalej jako: ustawa deweloperska).

2 Czech (2018): 398; Wszołek (2013): 147; Ganicz (2013): 212.

${ }^{3}$ Ciepła (2012): 110.

${ }^{4}$ Ciepła (2012): 110.
} 
perskiej - dotyczący odstapienia od umowy deweloperskiej - ma charakter bezwzględnie obowiąujący ${ }^{5}$.

Stanowisko wykluczające możliwość zastrzeżenia zadatku w umowie deweloperskiej nie zasługuje na aprobatę. Przepis art. 22 ustawy deweloperskiej, wskazujący, jakie postanowienia „w szczególności” zawiera umowa deweloperska, potwierdza dopuszczalność wzbogacenia jej treści przez strony na podstawie art. $353^{1}$ k.c., wynikająca z zasad ogólnych. Jednakże treść lub cel stosunku prawnego nie mogą sprzeciwiać się właściwości (naturze) stosunku, ustawie ani zasadom współżycia społecznego. Dodatkowe postanowienia umowy deweloperskiej nie moga więc między innymi naruszać norm semiimperatywnych, zawartych w ustawie deweloperskiej ${ }^{6}$, to znaczy nie moga kształtować sytuacji prawnej nabywcy w sposób mniej korzystny, niż wynika to z tej ustawy. Postanowienia umowy deweloperskiej mniej korzystne dla nabywców aniżeli przepisy ustawy deweloperskiej są nieważne, a zamiast nich stosuje się odpowiednie przepisy tej ustawy (art. 28 ustawy deweloperskiej). Ocena dopuszczalności ustanowienia zadatku w umowie deweloperskiej wymaga więc rozstrzygnięcia, czy ustanowienie zadatku jest mniej korzystne dla nabywcy niż rozwiązania ogólne zawarte w ustawie deweloperskiej.

$\mathrm{Z}$ art. 394 k.c. wynika, że w braku odmiennego zastrzeżenia umownego albo zwyczaju zadatek pełni funkcję zabezpieczająca wykonanie zobowiązania, a rolę tę należy uznać za preferowaną przez ustawodawcę, skoro występuje ona, gdy strony nie postanowią inaczej i gdy brak odmiennego zwyczaju? Nieco inaczej twierdzi się, że podstawową funkcję zadatku stanowi nie tyle zabezpieczenie wykonania zobowiązania przez jedną ze stron, ile umocnienie stosunku obligacyjnego po obydwu stronach ${ }^{8}$. W mojej ocenie wzmocnienie pozycji danej strony należy uznać za konsekwencję zakresu uprawnień przysługujących jej w razie zaistnienia okoliczności określonych przez ustawodawcę, a możliwość skorzystania z tych uprawnień może stanowić swoistą presję, skłaniającą dłużnika do wykonania zobowiązania zgodnie z jego treścią a więc zabezpieczać wykonanie zobowiązania we właściwy sposób ${ }^{9}$. Co do zasady więc ustanowienie zadatku jest korzystne dla obu stron umowy i zabezpieczając wykonanie zobowiązania, sprzyja umocnieniu pozycji obu stron umowy, w tym również umowy deweloperskiej ${ }^{10}$. Należy podkreślić, że modyfikacja wynikająca z art. $394 \S 1$ k.c., polegająca na uprawnieniu do odstapienia przez nabywcę od umowy bez konieczności wyznaczania terminu dodatkowego, jest korzystniejsza dla nabywcy niż reguła ogólna wynikająca z ustawy deweloperskiej (zgodnie z art. 29 ust. 3 zd. 1 ustawy deweloperskiej

5 Ciepła (2012): 109.

${ }^{6}$ Przez „ustawę” na gruncie art. $353^{1}$ k.c. rozumie się bezwzględnie wiążące i semiimperatywne normy prawne powszechnie obowiązującego prawa w Polsce - tak np.: Machnikowski (2005): 224-225; (2020): 589; (2019a): 700; Trzaskowski (2005): 222-223; Radwański, Olejniczak (2016): 131; Olejniczak (2014a): 45; Gutowski (2016): 1232; Rzetecka-Gil (2011).

7 Tenenbaum (2008a): 59; Ciszewski (2003): 29; Jasiński (1991): 54-55.

8 Tracz, Zoll (1996): 51.

9 Tenenbaum (2008a): 59.

10 Tak również Ganicz (2013): 318. 
w przypadku, o którym mowa w ust. 1 pkt 6 tej ustawy, przed skorzystaniem z prawa do odstapienia od umowy deweloperskiej nabywca wyznacza deweloperowi 120-dniowy termin na przeniesienie prawa, o którym mowa w art. 1 ustawy deweloperskiej, a w razie bezskutecznego upływu wyznaczonego terminu będzie uprawniony do odstapienia od tej umowy). Jednak niektóre skutki prawne zastrzeżenia zadatku, wynikające z art. 394 k.c., byłyby mniej korzystne dla nabywcy w stosunku do modelu ukształtowanego w ustawie deweloperskiej. Należy więc przyjąć, że ustanowienie zadatku w umowie deweloperskiej jest dozwolone, a modyfikacji ulegaja - w ograniczonym zakresie, wyznaczanym kryterium pogorszenia sytuacji nabywcy - skutki prawne ustanowienia zadatku, a ściślej przesłanki skorzystania z ustawowego prawa odstapienia od umowy na podstawie art. $394 \S 1$ k.c. ${ }^{11}$ W zakresie, w którym skutki ustanowienia zadatku określone w art. 394 k.c. byłyby mniej korzystne dla nabywcy niż przepisy ustawy deweloperskiej, skutki te nie wystapią i zastosowanie znajdą odpowiednie przepisy ustawy deweloperskiej.

$\mathrm{Na}$ marginesie należy także zaznaczyć, że reprezentowany przez Ciepła pogląd o bezwzględnie wiążącym charakterze norm prawnych zawartych w art. 29 ustawy deweloperskiej nie zasługuje na aprobatę. Ze względu na art. 28 ustawy deweloperskiej należy bowiem uznać, że normy te mają charakter semiimperatywny, w związku z czym dopuszczalność zastrzeżenia zadatku należy oceniać w sposób przedstawiony powyżej.

Wyrażane jest także stanowisko, zgodnie z którym „dopuszczalne jest [...] wprowadzenie do umowy deweloperskiej instytucji zadatku, jednak tylko jednostronnego - na korzyść nabywcy (z uwagi na treść art. 28 ustawy deweloperskiej), gdy stroną uprawnioną do odstapienia od umowy bez wymogu wyznaczania deweloperowi terminu dodatkowego do spełnienia świadczenia będzie nabywca"12. Powyższy pogląd, zgodnie z którym ustanowienie zadatku skutkuje możliwością odstapienia od umowy w razie spełnienia przesłanki określonej w art. $394 \$ 1$ k.c. (niewykonanie umowy przez jedna ze stron z powodu okoliczności, za które ponosi ona wyłączną odpowiedzialność) bez wyznaczania terminu dodatkowego jedynie przez nabywcę, jest słuszny. Również deweloper w razie spełnienia wymienionej wyżej przesłanki będzie uprawniony do odstąpienia od umowy na podstawie art. $394 \$ 1$ k.c., będzie jednak musiał zachować rygory określone w art. 29 ust. 4 ustawy deweloperskiej - ze względu na art. 28 ustawy deweloperskiej, z którego wynika semiimperatywny charakter normy prawnej wyrażonej w art. 29 ust. 4 ustawy deweloperskiej. W związku z powyższym zaproponowane przez Monikę Drelę określenie ,jednostronny zadatek" nie może być rozumiane w ten sposób, że wszelkie konsekwencje prawne ustanowienia zadatku odnosza się jedynie do nabywcy (ponieważ w przypadku ustanowienia zadatku w umowie deweloperskiej również deweloper w razie spełnienia przesłanki z art. $394 \S 1$ k.c. może odstapić od umowy na

11 Podobnie Ganicz (2013): 319.

12 Drela (2013): 324. 
podstawie tego przepisu i zachować otrzymany przedmiot zadatku, chociaż nie będzie mógł tego uczynić bez wyznaczenia terminu dodatkowego z przedstawionych wyżej powodów).

\section{Klauzula zadatku jako niedozwolone postanowienie umowy konsumenckiej}

W literaturze podkreśla się, że klauzula zadatku może niekiedy stanowić niedozwolone postanowienie umowne, co dotyczy umów deweloperskich o charakterze konsumenckim ${ }^{13}$. Zgodnie z art. $385^{1} \S 1$ k.c. postanowienia umowy zawieranej z konsumentem nieuzgodnione indywidualnie nie wiążą go bowiem, jeżeli kształtują jego prawa i obowiązki w sposób sprzeczny z dobrymi obyczajami, rażąco naruszając jego interesy (niedozwolone postanowienia umowne). Nie dotyczy to jednak postanowień określających główne świadczenia stron, w tym cenę lub wynagrodzenie, jeżeli zostały sformułowane w sposób jednoznaczny. Nieuzgodnione indywidualnie są te postanowienia umowy, na których treść konsument nie miał rzeczywistego wpływu, co w szczególności odnosi się to do postanowień umowy przejętych z wzorca umowy zaproponowanego konsumentowi przez kontrahenta (art. $385^{1} \S 3$ k.c.). W razie gdy postanowienie umowy nie wiąże konsumenta, strony sa związane umowa w pozostałym zakresie (art. $385^{1} \S 2$ k.c.). W kontekście abuzywnych postanowień umów deweloperskich związanych z ustanowieniem zadatku w literaturze zwraca się uwagę na art. $385^{3}$ pkt 12 i 13 k.c. ${ }^{14}$

Tytułem wstępu należy zauważyć, że postanowienie dotyczące zadatku może stanowić niedozwoloną klauzulę umowną. W szczególności nie przekonuje pogląd wyrażony przez Sebastiana Kowalskiego, zgodnie z którym ze względu na realny charakter zadatku, postanowienie dotyczące go nie może zostać uznane za niedozwoloną klauzulę umowna, ponieważ skuteczne zastrzeżenie zadatku - wymagające złożenia oświadczeń woli wraz z wręczeniem pieniędzy lub rzeczy przy zawarciu umowy - następuje poprzez indywidualnie uzgodnione postanowienia umowne (art. $385^{1} \S 1$ k.c.). Strona bowiem zawsze wie, ile daje (bądź otrzymuje) tytułem zadatku, i ma możliwość łatwego dokonania ceny skutków tej czynności ${ }^{15}$. Należy zgodzić się z Adamem Olejniczakiem, że znajomość przez konsumenta wysokości i skutków zastrzeżenia zadatku nie oznacza faktu indywidualnego uzgodnienia tego postanowienia umowy. W myśl art. $385^{1} \S 3$ k.c. nieuzgodnione indywidualnie sa bowiem te postanowienia umowne, na których treść konsument nie miał rzeczywistego wpływu. Zastrzeżenie zadatku podlega więc ocenie na podstawie art. $385^{1}-385^{3}$ k.c. i realny charakter zadatku nie jest przeszkoda dla uznania, że zastrzeżenie zadatku we wzorcu umowy stanowi niedozwoloną klauzulę umowną ${ }^{16}$.

\footnotetext{
${ }^{13}$ Czech (2018): 399.

${ }_{14}$ Czech (2018): 399.

15 Tak Kowalski (2003): 53-54.

16 Olejniczak (2020): 1215.
} 
Przede wszystkim należy zaznaczyć, że zgodnie z art. 28 ustawy deweloperskiej postanowienia umowy deweloperskiej mniej korzystne dla nabywców aniżeli przepisy tej ustawy są nieważne, a w ich miejsce stosuje się odpowiednie przepisy ustawy deweloperskiej. Jeżeli więc klauzula zadatku jest mniej korzystna dla nabywcy będącego konsumentem niż przepisy ustawy deweloperskiej, zastosowanie znajdzie sankcja nieważności przewidziana w art. 28 ustawy deweloperskiej i nie będzie zachodziła potrzeba badania tej klauzuli pod kątem jej abuzywności. Konieczne jest także podkreślenie, że regulacja zawarta w art. $385^{1}$ i n. k.c. dotyczy jedynie umów zawieranych z konsumentem, a więc z osobą fizyczną dokonująca z przedsiębiorcą czynności prawnej niezwiązanej bezpośrednio z jej działalnościa gospodarczą lub zawodowa (art. $22^{1}$ k.c.). O ile deweloper posiada status przedsiębiorcy (art. 3 pkt 1 ustawy deweloperskiej), to nabywca nie musi być konsumentem (art. 3 pkt 4 ustawy deweloperskiej).

Jak wskazano wyżej, w kontekście abuzywności klauzuli zadatku zamieszczonej w umowie deweloperskiej w literaturze wskazuje się dwa przepisy. Zgodnie z pierwszym z nich, tj. art. $385^{3}$ pkt 12 k.c., w razie watpliwości uważa się, że niedozwolonymi postanowieniami umownymi sa te, które w szczególności wyłączaja obowiązek zwrotu konsumentowi uiszczonej zapłaty za świadczenie niespełnione w całości lub części, jeżeli konsument zrezygnuje z zawarcia umowy lub jej wykonania. Natomiast w myśl drugiego z nich, tj. art. $385^{3}$ pkt 13 k.c., w razie wątpliwości uważa się, że niedozwolonymi postanowieniami umownymi są te, które w szczególności przewiduja utratę prawa żądania zwrotu świadczenia konsumenta spełnionego wcześniej niż świadczenie kontrahenta, gdy strony wypowiadaja, rozwiązują lub odstępują od umowy.

W kontekście sumy stanowiacej przedmiot zadatku, do której zatrzymania zgodnie $\mathrm{z}$ art. $394 \S 1$ k.c. byłby uprawniony deweloper w razie odstapienia od umowy, można mieć wątpliwości, czy suma ta stanowi zapłatę za świadczenie niespełnione przez dewelopera wskutek rezygnacji konsumenta z wykonania umowy (skutkującej odstąpieniem od umowy przez dewelopera), o której mowa w art. $385^{3}$ pkt 12 k.c. Zgodnie z art. 3 ust. 5 ustawy deweloperskiej umowa deweloperska oznacza umowę, na podstawie której deweloper zobowiązuje się do ustanowienia lub przeniesienia na nabywcę po zakończeniu przedsięwzięcia deweloperskiego prawa, o którym mowa $\mathrm{w}$ art. 1 tej ustawy, a nabywca zobowiązuje się do spełnienia świadczenia pieniężnego na rzecz dewelopera na poczet ceny nabycia tego prawa. Należy więc podkreślić, że w umowie deweloperskiej nabywca zobowiązuje się do spełnienia świadczenia pieniężnego na poczet ceny nabycia tego prawa, a więc z wyprzedzeniem. Oznacza to, że świadczenia pieniężne, do których spełnienia zobowiąuje się nabywca w umowie deweloperskiej, mają co do zasady charakter zaliczek na poczet ceny nabycia ${ }^{17}$. W razie ustanowienia zadatku jego przedmiot będzie pełnił funkcję zaliczki dopiero w przypadku

17 Ganicz (2013): 211-212. 
wykonania umowy deweloperskiej, gdy zgodnie z art. $394 \S 2$ k.c. ulegnie zaliczeniu na poczet świadczenia strony, która go dała. A contrario więc w razie rezygnacji przez nabywcę z wykonania umowy, skutkującej odstapieniem od niej przez dewelopera, takie zaliczenie nie następuje. Wypada także zaznaczyć, że w literaturze w kontekście art. $385^{3}$ pkt 12 k.c. wskazuje się na świadczenia wynikające z umowy wzajemnej ${ }^{18}$, a więc - jak można sądzić główne świadczenia stron.

Wątpliwości budzi także drugi z przytaczanych w literaturze przypadków. Opierając się na wykładni językowej art. $385^{3}$ pkt 13 k.c., można twierdzić, że wręczenie sumy pieniężnej stanowiącej przedmiot zadatku może zostać uznane za świadczenie konsumenta spełnione wcześniej niż świadczenie kontrahenta (art. $385^{3}$ pkt 13 k.c.). Wątpliwości powstaja jednak, jeśli wziąć pod uwagę ratio legis art. $385^{3}$ pkt 13 k.c. Intencja ustawodawcy wydaje się polegać na tym, by w razie utraty skuteczności przez umowę nie aktualizowało się uprawnienie kontrahenta konsumenta do zatrzymania świadczenia spełnionego przez konsumenta wcześniej niż świadczenie kontrahenta. Również w tym przypadku ustawodawca zdaje się więc zakładać związek między świadczeniami obu stron i zdaje się dążyć do przeciwdziałania temu, by okoliczność utraty skuteczności przez umowę uprawniała kontrahenta konsumenta do zatrzymania otrzymanego przez niego świadczenia, podczas gdy on swego świadczenia nie wykonał. Tymczasem funkcja odszkodowawcza przedmiotu zadatku jest związana nie tylko z samym faktem odstapienia od umowy, lecz aktualizuje się wówczas, gdy przyczyną odstapienia było niewykonanie umowy przez jedną ze stron z powodu okoliczności, za które ponosi ona wyłączną odpowiedzialność. Uprawnienie do zatrzymania przedmiotu zadatku otrzymanego przez kontrahenta konsumenta nie jest więc związane z samą przypadkową okolicznościa utraty mocy przez umowę, lecz stanowi konsekwencję negatywnego zachowania się konsumenta (niewykonania przez niego umowy z powodu okoliczności, za które ponosi on wyłączną odpowiedzialność), które zaktualizowało uprawnienie kontrahenta konsumenta do odstapienia od umowy i zatrzymania przedmiotu zadatku. Ponadto można uznać, że art. $385^{3}$ pkt 13 k.c. dotyczy świadczeń istotnych dla danego typu umowy, a świadczenie spełnione tytułem zadatku do takich nie należy - ma charakter uboczny, nie jest świadczeniem charakterystycznym dla umowy.

Jak już wskazano, w literaturze w kontekście zadatku wymienia się wyłącznie omówione wyżej dwa przepisy. Wypada jednak zwrócić uwagę na to, że zgodnie z art. $385^{3}$ pkt 2 k.c. w razie wątpliwości uważa się, że niedozwolonymi postanowieniami umownymi sa te, które w szczególności wyłączają lub istotnie ograniczają odpowiedzialność względem konsumenta za niewykonanie lub nienależyte wykonanie zobowiązania. Zastrzeżenie zadatku prowadzi natomiast - w braku zastrzeżenia przez strony możliwości dochodzenia odszkodowania uzupełniającego - do zryczałtowania odpowiedzialności odszkodowawczej za niewykonanie zobowiązania, za które jedna ze stron ponosi

18 Żuławska, aktualizacja Trzaskowski (2013): 192. 
wyłączną odpowiedzialność, ponieważ funkcję odszkodowania pełni wówczas przedmiot zadatku bądź suma dwukrotnie wyższa ${ }^{19}$. Nie podzielam bowiem stanowiska, zgodnie z którym w razie zastrzeżenia zadatku i niewykonania zobowiązania z powodu okoliczności, za które jedna ze stron ponosi wyłączna odpowiedzialność, druga strona może skorzystać z uprawnień przewidzianych w art. $394 \S 1$ k.c. bądź nie odstępując od umowy, żądać odszkodowania w pełnej wysokości na podstawie art. $471 \mathrm{i}$ n. k.c. ${ }^{20}$ Ustanowienie zadatku może więc oznaczać istotne ograniczenie odpowiedzialności względem konsumenta za niewykonanie zobowiązania, skoro co do zasady prowadzi do zryczałtowania odpowiedzialności odszkodowawczej za niewykonanie zobowiązania i niemożliwe jest dochodzenie odszkodowania uzupełniającego, aż do pokrycia w pełnej wysokości poniesionej szkody ${ }^{21}$. Zryczałtowanie odpowiedzialności odszkodowawczej w kontekście ochronnego celu normy prawnej zawartej w art. $385^{3}$ pkt 2 k.c. należy uznać za istotne ograniczenie odpowiedzialności względem konsumenta za niewykonanie lub nienależyte wykonanie zobowiązania (w przypadku zadatku: za niewykonanie zobowiązania), a tym samym klauzula zadatku może stanowić niedozwolone postanowienie umowne. Wydaje się więc, że należałoby uznać, iż konsument nie jest wówczas związany skutkiem zastrzeżenia zadatku, polegającym na niedopuszczalności żądania odszkodowania uzupełniającego, przewyższającego sumę dwukrotnie wyższą niż przedmiot zadatku.

W kontekście uznania ustanowienia zadatku za istotne ograniczenie odpowiedzialności względem konsumenta za niewykonanie zobowiązania należy podkreślić, że istotny jest sam fakt zryczałtowania odpowiedzialności odszkodowawczej, a nie to, jak duża szkoda została poniesiona przez konsumenta w konkretnym przypadku. Przeciwne stanowisko - polegające na przyjęciu za punkt odniesienia szkody poniesionej przez konsumenta w danym przypad$\mathrm{ku}$ - należy odrzucić przede wszystkim dlatego, że wymagałoby dokonywania oceny ex post, już po doznaniu szkody przez konsumenta, nie zaś w chwili zawarcia umowy. Ponadto odrzucane tu stanowisko prowadziłoby do obciążenia konsumenta obowiązkiem wykazania wysokości poniesionej przez niego szkody, co czyniłoby ochronę konsumenta iluzoryczną. W razie ustanowienia zadatku jednym z udogodnień jest zaś generalnie brak konieczności wykazywania faktu poniesionej szkody i jej wysokości.

Abuzywny charakter klauzuli zadatku może być także konsekwencja określonych umownych modyfikacji w stosunku do ustawowych skutków zastrzeżenia zadatku. Wówczas przy dokonywaniu oceny abuzywności tego postanowienia należy ocenić treść konkretnej klauzuli zadatku oraz jej skutki prawne.

Podsumowując, nie można wykluczyć, że określone postanowienie umowy deweloperskiej, które nie jest mniej korzystne dla nabywcy niż postanowienia

19 Tenenbaum (2008a): 59-61; Tenenbaum-Kulig (2018a): 292; Olejniczak (2014b): 329-330; (2020): 1226.

${ }^{20}$ Tenenbaum (2008a): 289-294; Tenenbaum-Kulig (2010): 639-650; (2018a): 291.

${ }^{21}$ Tenenbaum (2008a): 299 i cytowana tam literatura; Olejniczak (2005): 1255; (2020): 1228; (2014b): 331; Popiołek (2005): 1047; Zakrzewski (2018): 322. 
ustawy deweloperskiej (a więc nie jest nieważne na podstawie art. 28 ustawy deweloperskiej) może zostać uznane w danym przypadku za niedozwolone postanowienie umowne w rozumieniu art. $385^{1}$ k.c. ${ }^{22}$

\section{USTANOWIENIE ZADATKU W UMOWIE DEWELOPERSKIEJ}

Klauzula zadatku stanowi dodatkowe zastrzeżenie umowne ${ }^{23}$ i jako taka jest elementem umowy deweloperskiej, zawieranej w formie aktu notarialnego (art. 26 ust. 1 ustawy deweloperskiej). Postanowienie dotyczące zadatku może stanowić od samego początku element umowy deweloperskiej bądź może zostać do niej dodane w wyniku uzupełnienia tej umowy.

W praktyce $\mathrm{w}$ umowach deweloperskich zadatek jest zastrzegany na rzecz dewelopera, a jego przedmiot ma charakter pieniężny. Suma pieniężna uiszczana tytułem zadatku powinna zostać wpłacona na mieszkaniowy rachunek powierniczy zapewniony nabywcy przez dewelopera (art. 4 ustawy deweloperskiej) ${ }^{24}$. W związu z realnym charakterem klauzuli zadatku do jego ustanowienia dochodzi w chwili dokonania odpowiedniego zapisu na rachunku bankowym ${ }^{25}$.

Ustanowienie zadatku w umowie deweloperskiej następuje zgodnie z zasadami wynikajacymi z art. $394 \S 1$ k.c. Obowiązuje więc reguła interpretacyjna, zgodnie z którą w braku odmiennego zastrzeżenia umownego albo zwyczaju suma pieniężna dana przy zawarciu umowy stanowi przedmiot zadatku, jak również strony mogą wyraźnie postanowić w umowie, że określona suma pieniężna zostaje wpłacona ze skutkami zadatku (wówczas przedmiot zadatku może zostać dany w innym momencie niż przy zawarciu umowy, w szczególności w terminie późniejszym). Skorzystanie z tego drugiego rozwiązania będzie konieczne dla możliwości uznania określonej sumy pieniężnej wpłaconej przez nabywcę za przedmiot zadatku, jednak nie - jak twierdzi się w literaturze ze względu na to, że w przypadku umowy deweloperskiej przedmiot zadatku jest wpłacany w innym momencie niż „przy zawarciu umowy”"26. Postanowienie przez strony, że suma pieniężna zostaje uiszczona tytułem zadatku, jest niezbędne dlatego, że skutki określone w art. 394 k.c. znajdują zastosowanie w braku odmiennego zastrzeżenia umownego albo zwyczaju (art. 394 $\S 1$ k.c.), a przez umowę deweloperską nabywca zobowiązuje się do spełnienia

${ }^{22}$ Burzak, Okoń, Pałka (2012): 282.

${ }^{23}$ Tenenbaum (2008a): 131-138 i cytowana tam literatura; Olejniczak (2020): 1212; (2019): 14; Machnikowski (2019b): 835. Inaczej: Lemkowski (2016: 1501) uznający, że art. 39 k.c. reguluje ustawowe, dodatkowe skutki czynności prawnej, tj. umowy, przy zawieraniu której jest dawany zadatek. Występuje również pogląd, zgodnie z którym postanowienie ustanawiające zadatek ma charakter odrębnej umowy - tak Domański (1936): 380; Pyrzyńska (2001): 108; orzeczenie SN z 30 listopada 1937 r., C II 1773/37, Zbiór Orzeczeń Sądu Najwyższego 1938, z. IX, poz. 412; orzeczenie SN z 20 sierpnia 1948 r., C I. 419/48, Przegląd Notarialny 1949, z. 3/4, s. 318.

${ }_{24}^{24}$ Tak również: Czech (2018): 399; Ganicz (2013): 212-213.

${ }^{25}$ Olejniczak (2020): 1215; Tenenbaum (2008a): 201-202; Tenenbaum-Kulig (2018a): 286.

${ }^{26}$ Tak Ganicz (2013): 212-213. 
świadczenia pieniężnego na rzecz dewelopera na poczet ceny nabycia prawa, o którym mowa w art. 1 ustawy deweloperskiej (art. 3 pkt 5 ustawy deweloperskiej). Umowa spełniajacca essentialia negotii umowy deweloperskiej zawiera więc zobowiązanie się nabywcy do spełnienia świadczenia pieniężnego na rzecz dewelopera na poczet ceny nabycia. W konsekwencji sumy pieniężne uiszczane przez nabywcę stanowią zasadniczo zaliczki na poczet ceny nabycia prawa, do którego ustanowienia lub przeniesienia na nabywcę po zakończeniu przedsięwzięcia deweloperskiego zobowiązuje się deweloper ${ }^{27}$. Aby określona suma pieniężna wpłacona przez nabywcę mogła stanowić przedmiot zadatku, niezbędne jest więc określenie takiego jej charakteru przez strony umowy deweloperskiej.

W literaturze twierdzi się jednak, że konieczność określenia w umowie deweloperskiej, iż dana kwota jest wpłacana tytułem zadatku, wynika z tego, że kwota wręczona deweloperowi później niż przy zawarciu umowy deweloperskiej nie może być uznana za uiszczona tytułem zadatku, chyba że co innego wynika z treści umowy, wszelkie zaś płatności dokonywane przez nabywcę, w tym również przedmiot zadatku, powinny być uiszczane na mieszkaniowy rachunek powierniczy ${ }^{28}$. Prawdą jest, że reguła interpretacyjna z art. $394 \S 1$ k.c. znajduje zastosowanie wyłącznie odnośnie do sumy pieniężnej lub rzeczy danej przy zawarciu umowy, lecz określenie „przy zawarciu umowy” nie powinno być rozumiane dosłownie. Wymóg zachowania ścisłej zbieżności czasowej zawarcia umowy i wydania przedmiotu zadatku należy uznać za spełniony, jeżeli niezwłocznie po zawarciu umowy (np. następnego dnia) strona podjęła wszystkie czynności, które są niezbędne w danej sytuacji do zmiany faktycznego władztwa nad przedmiotem zadatku, a więc na przykład wpłaciła pieniądze, czy też wydała polecenie przelewu środków pieniężnych na rachunek bankowy ${ }^{29}$. Tak więc jeżeli nabywca niezwłocznie po zawarciu umowy deweloperskiej podejmie czynności niezbędne do wpłaty określonej sumy pieniężnej na mieszkaniowy rachunek powierniczy, którego numer został podany w umowie deweloperskiej (zob. art. 22 ust. 1 pkt 9 lit. a ustawy deweloperskiej), można będzie uznać, że wpłacona na niego suma pieniężna została dana przy zawarciu umowy w rozumieniu art. 394 § 1 k.c. Jednak jak wskazano wyżej, zgodnie z art. $394 \S 1$ k.c. suma pieniężna lub rzecz dana przy zawarciu umowy wywołuje skutki prawne określone w tym przepisie w braku odmiennego zastrzeżenia umownego albo zwyczaju. Skoro więc w umowie deweloperskiej nabywca zobowiąuje się generalnie do spełnienia świadczenia pieniężnego na rzecz dewelopera na poczet ceny nabycia określonego prawa (a więc jako zaliczki, stanowiącej odrębną od zadatku instytucję prawną ${ }^{30}$ ), to w razie niesprecyzowania tytułu wpłaty bądź polecenia przelewu wykładnia oświadczeń

27 Ganicz (2013): 211-212.

28 Tak: Ganicz (2013): 212-213.

${ }^{29}$ Olejniczak (2005): 1247; (2014b): 323; Tenenbaum-Kulig (2018a): 285. Zob. też: Szostek (2005): 1411; Drapała (2001): 143; Tenenbaum (2008a): 198; Lemkowski (2016): 1504; Zakrzewski (2018): 317.

${ }^{30}$ Zob. Tenenbaum (2008a): 345; Tenenbaum (2008b): 132-149; Tenenbaum-Kulig (2018b): 306-309. 
woli prowadzi do wniosku, że suma pieniężna jest uiszczana jako zaliczka, a bierną postawę dewelopera należy uznać za akceptację takiego charakteru wpłaconych środków. W konsekwencji dla możliwości uznania określonej kwoty pieniężnej wpłaconej przez nabywcę za uiszczoną tytułem zadatku niezbędne jest odpowiednie postanowienie umowne, niezależnie od chwili dokonania przez nabywcę czynności wymaganych do przekazania deweloperowi tej sumy. Postanowienie o zastrzeżeniu zadatku - jako element umowy deweloperskiej - powinno mieć formę aktu notarialnego. Zastrzeżenie zadatku możliwe jest także we wzorcu umowy, lecz ze względu na realny charakter klauzuli zadatku skuteczność tego postanowienia zależy od konsensu stron, obejmującego to dodatkowe zastrzeżenie umowne ${ }^{31}$.

\section{PODSUMOWANIE I WNIOSKI KOŃCOWE}

Przeprowadzona analiza prowadzi do wniosku o generalnej dopuszczalności zastrzegania zadatku w umowie deweloperskiej, przy czym modyfikacji ulegaja - w ograniczonym zakresie, wyznaczanym kryterium pogorszenia sytuacji nabywcy - skutki prawne ustanowienia zadatku, a konkretnie przesłanki skorzystania z ustawowego prawa odstapienia od umowy na podstawie art. $394 \S 1$ k.c. W zakresie, w którym skutki ustanowienia zadatku określone w art. 394 k.c. byłyby mniej korzystne dla nabywcy niż przepisy ustawy deweloperskiej, skutki te nie wystapią i zastosowanie znajdą odpowiednie przepisy ustawy deweloperskiej. W przypadku umów deweloperskich o charakterze konsumenckim klauzula zadatku może jednak stanowić niedozwolone postanowienie umowne, ponieważ art. $385^{3}$ pkt 2 k.c. nakazuje w razie wątpliwości uznać za niedozwolone postanowienia umowne te, które istotnie ograniczają odpowiedzialność względem konsumenta za niewykonanie lub nienależyte wykonanie zobowiązania. Zryczałtowanie odpowiedzialności odszkodowawczej z tytułu niewykonania zobowiązania, za które deweloper ponosi wyłączną odpowiedzialność, należy uznać za istotne ograniczenie odpowiedzialności względem konsumenta za niewykonanie zobowiązania (niezależnie od poniesionej w danym przypadku przez konsumenta szkody), co prowadzi do wniosku, że konsument nie jest związany skutkiem zastrzeżenia zadatku, polegającym na niedopuszczalności żądania odszkodowania uzupełniającego, przewyższającego sumę dwukrotnie wyższą niż dany przez niego przedmiot zadatku. Abuzywny charakter klauzuli zadatku może także stanowić konsekwencję określonych umownych modyfikacji przyjętych przez strony w stosunku do ustawowych skutków zastrzeżenia zadatku.

$\mathrm{W}$ praktyce w umowach deweloperskich zadatek jest zastrzegany na rzecz dewelopera, a jego przedmiot ma charakter pieniężny. Dla uznania określonej sumy wpłacanej przez nabywcę za uiszczaną tytułem zadatku niezbędne jest postanowienie przez strony umowy deweloperskiej w formie aktu nota-

${ }^{31}$ Olejniczak (2014b): 323; (2020): 1214-1215; Tenenbaum-Kulig (2018a): 288. 
rialnego, że suma pieniężna zostaje wpłacona ze skutkami zadatku. Wpłata powinna zostać dokonana na mieszkaniowy rachunek powierniczy zapewniony nabywcy przez dewelopera, a do ustanowienia zadatku dochodzi w chwili dokonania odpowiedniego zapisu na rachunku bankowym.

Monika Tenenbaum-Kulig

Uniwersytet Wroctawski

monika.tenenbaum-kulig@uwr.edu.pl

https://orcid.org/0000-0001-7539-6351

Burzak, A., Okoń, M., Pałka, P. (2012). Ochrona praw nabywcy lokalu mieszkalnego lub domu jednorodzinnego. Komentarz. Warszawa.

Ciepła, H. (2012). Art. 22. Treść umowy deweloperskiej, [w:] H. Ciepła, B. Szczytowska, Ustawa o ochronie praw nabywcy lokalu mieszkalnego i domu jednorodzinnego. Komentarz. Wzory umów deweloperskich i pism. Warszawa: 106-110.

Ciszewski, J. (2003). Ustawowe i umowne ograniczenia odpowiedzialności osobistej. Gdańskie Studia Prawnicze 10: 17-30.

Czech, T. (2018). Ustawa deweloperska. Komentarz Warszawa.

Domański, L. (1936). Instytucje kodeksu zobowiązań. Warszawa.

Drapała, P. (2001). Glosa do wyroku Sądu Najwyższego z dnia 7 października 1999 r., I CKN 262/98, OSNC 2000, z. 4, poz. 71. Radca Prawny 1: 139-143.

Drela, M. (2013). Komentarz do art. 29, [w:] I. Kredzińska (red.), Ustawa deweloperska. Komentarz praktyczny do ustawy o ochronie praw nabywcy lokalu mieszkalnego lub domu jednorodzinnego. Wrocław: 314-324.

Ganicz, A. (2013). Umowa deweloperska, Rozprawa doktorska przygotowana pod kierunkiem prof. dr hab. Piotra Machnikowskiego na Wydziale Prawa, Administracji i Ekonomii Uniwersytetu Wrocławskiego, w Instytucie Prawa Cywilnego, Zakładzie Prawa Cywilnego i Prawa Międzynarodowego Prywatnego. Wrocław (niepublikowana).

Gutowski, M. (2016). Komentarz do art. $353^{1}$ k.c., [w:] M. Gutowski (red.), Kodeks cywilny. Tom 1: Komentarz. Art. 1-449 ${ }^{11}$. Warszawa: 1228-1248.

Jasiński, A. (1991). Wybrane formy zabezpieczenia wierzytelności pieniężnych. Rejent 3: 40-56.

Kowalski, S. (2003). Charakter częściowej wpłaty przy umowie sprzedaży, Glosa do wyroku Sądu Najwyższego z 13 lutego 2002 r. (sygn. akt IV CKN 672/00). Prawo Spółek 10: 51-54.

Lemkowski, M. (2016). Komentarz do art. 394 k.c., [w:] M. Gutowski (red.), Kodeks cywilny, Tom 1: Komentarz. Art. 1-44911. Warszawa: 1500-1513.

Machnikowski, P. (2005). Swoboda umów według art. $353^{1}$ KC. Konstrukcja prawna Warszawa.

Machnikowski, P. (2019a). Komentarz do art. $353^{1}$ k.c., [w:] E. Gniewek, P. Machnikowski (red.), Kodeks cywilny. Komentarz. Warszawa: 696-702.

Machnikowski, P. (2019b). Komentarz do art. 394 k.c., [w:] E. Gniewek, P. Machnikowski (red.), Kodeks cywilny. Komentarz. Warszawa: 833-837.

Machnikowski, P. (2020). Treść umowy, [w:] K. Osajda (red.), System prawa prywatnego. Tom 5: Prawo zobowiązań - część ogólna. Warszawa: 564-648.

Olejniczak, A. (2005). Uwagi o zastrzeganiu zadatku w umowach przygotowujących zawarcie umów zasadniczych, [w:] L. Ogiegło, W. Popiołek, M. Szpunar (red.), Rozprawy prawnicze, Księga pamiątkowa Profesora Maksymiliana Pazdana. Kraków: 1233-1256.

Olejniczak, A. (2014a). Komentarz do art. $353^{1}$ k.c., [w:] A. Kidyba (red.), Kodeks cywilny. Komentarz. Tom 3: Zobowiązania. Część ogólna. Warszawa: 42-50.

Olejniczak, A. (2014 B). Komentarz do art. 394 k.c., [w:] A. Kidyba (red.), Kodeks cywilny. Komentarz. Tom 3: Zobowiązania. Część ogólna. Warszawa: 320-336.

Olejniczak, A. (2019). Charakter prawny ustanowienia zadatku. Palestra 5: 13-25.

Olejniczak, A. (2020). Zadatek, [w:] red. K. Osajda, System prawa prywatnego. Tom 5: Prawo zobowiązań - część ogólna. Warszawa: 1207-1242.

Popiołek, W. (2005). Komentarz do art. 394 k.c., [w:] K. Pietrzykowski (red.), Kodeks cywilny. Tom 1: Komentarz do artykułów 1-44911. Warszawa: 1045-1049. 
Pyrzyńska, A. (2001). Glosa do wyroku z dnia 07 X 1999, I CKN 262/98. Państwo i Prawo 56(10): $106-110$.

Radwański, Z., Olejniczak, A. (2016). Zobowiązania - część ogólna. Warszawa.

Rzetecka-Gil, A. (2011). Kodeks cywilny. Komentarz. Zobowiązania - część ogólna. Lex/el.

Szostek, D. (2005). Zadatek w umowach zawieranych w postaci elektronicznej, [w:] L. Ogiegło, W. Popiołek, M. Szpunar (red.), Rozprawy prawnicze. Księga pamiątkowa Profesora Maksymiliana Pazdana. Kraków: 1407-1417.

Tenenbaum, M. (2008a). Instytucja zadatku w polskim prawie cywilnym. Warszawa.

Tenenbaum, M. (2008b). Instytucje zadatku i zaliczki - cechy wspólne, różnice i kryteria rozróżnienia. Rejent 9: 132-149.

Tenenbaum-Kulig, M. (2010). Uprawnienia wierzyciela nieodstępującego od umowy zabezpieczonej zadatkiem - na tle uchwały Sądu Najwyższego z 25.6.2009 r. (III CZP 39/09), [w:] J. Gołaczyński, P. Machnikowski (red.), Współczesne problemy prawa prywatnego. Księga pamiątkowa ku czci Profesora Edwarda Gniewka. Warszawa: 639-650.

Tenenbaum-Kulig, M. (2018a). Klauzula zadatku, [w:] R. Strugała (red.), Wykładnia umów, Standardowe klauzule umowne. Komentarz praktyczny z przeglądem orzecznictwa, Wzory umów. Warszawa: 277-301.

Tenenbaum-Kulig, M. (2018b). Klauzula zaliczki, [w:] R. Strugała (red.), Wykładnia umów, Standardowe klauzule umowne, Komentarz praktyczny z przeglądem orzecznictwa, Wzory umów. Warszawa: 305-312.

Tracz, G., Zoll, F. (1996). Przewłaszczenie na zabezpieczenie. Praktyka, konstrukcja, dopuszczalność, przedmiot. Kraków.

Trzaskowski, R., Granice swobody kształtowania treści i celu umów obligacyjnych, Art. $353^{1}$ K.C. Kraków 2005. Warszawa 2013.

Zakrzewski, P. (2018). Komentarz do art. 394 k.c., [w:] M. Habdas, M. Fras (red.), Kodeks cywilny. Komentarz. Tom 3: Zobowiązania. Część ogólna (art. 353-534). Warszawa: 313-325.

Żuławska, C., aktualizacja R. Trzaskowski (2013). Komentarz do art. $385^{3}$ k.c., [w:] J. Gudowski (red.), Kodeks cywilny. Komentarz. Tom 3, cz. 1: Zobowiązania. Warszawa: 187-197.

\section{STIPULATING A PRELIMINARY PAYMENT IN A DEVELOPER AGREEMENT}

S u m m a r y

The article concerns the issue of the admissibility of stipulating a preliminary payment in a developer agreement. This subject was analysed in the context of the semi-imperative nature of legal norms contained in the Developer Act. Consideration is given to which results of establishing a preliminary payment are less favourable to the buyer, and thus will not occur in the analysed case. The subject of analysis was also the issue of whether a preliminary payment clause may constitute a prohibited provision in a consumer contract. The second part of the work concerns how to establish a preliminary payment in a developer agreement. It explains the issues regarding how to stipulate a preliminary payment in the developer agreement, the form of such a clause, the subject of the preliminary payment, and how it can be transferred.

Keywords: preliminary payment; developer agreement; prohibited contractual clauses; establishing a preliminary payment 